\title{
Semilla Sandstone, a New
}

Member of the Mancos Shale

\section{In the Southeastern Part of the}

\section{San Juan Basin, New Mexico}

By CARLE H. DANE, ERLE G. KAUFFMAN, and WILLIAM A. COBBAN

CONTRIBUTIONS TO STRATIGRAPHY

GE OLOGICAL S U R VEY B U L E T I N $1254-\mathrm{F}$

Definition, description, and paleontology of a new stratigraphic unit 


\title{
UNITED STATES DEPARTMENT OF THE INTERIOR
}

STEWART L. UDALL, Secretary

\author{
GEOLOGICAL SURVEY \\ William T. Pecora, Director
}

U.S. GOVERNMENT PRINTING OFFICE WASHINGTON : 1968 


\section{CONTENTS}

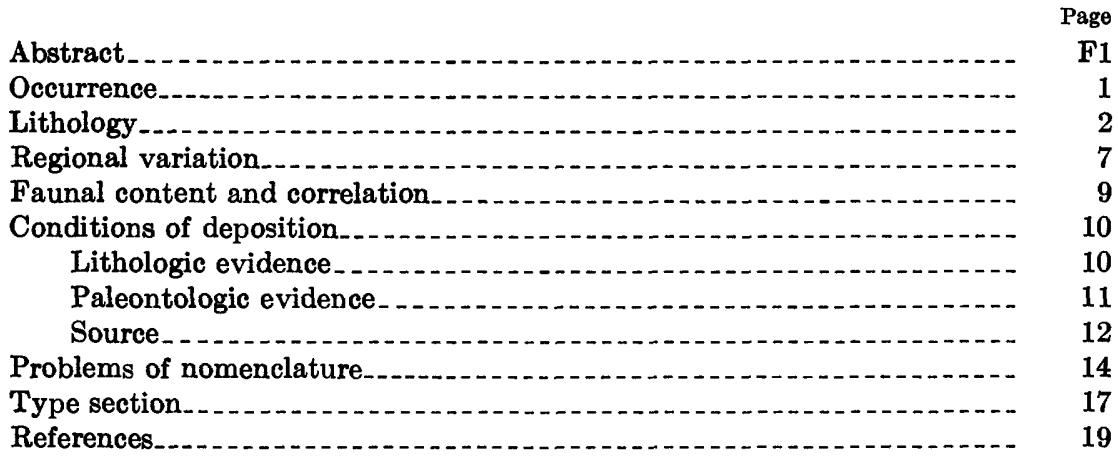

\section{ILLUSTRATIONS}

Figure 1. Map showing location of type section of Semilla Sandstone Member of Mancos Shale and its outcrop in the nearby area. 2-4. Photographs of:

2. Cuesta ridge of Semilla Sandstone Member of Mancos Shale and underlying dark-gray shale..............

3. Type section of Semilla Sandstone Member of Mancos Shale. . . . . . . . .

4. Concretions weathered out of lower part of Semilla Sandstone Member of Mancos Shale. 



\title{
CONTRIBUTIONS TO STRATIGRAPHY
}

\section{SEMILLA SANDSTONE, A NEW MEMBER OF THE MANCOS SHALE IN THE SOUTHEASTERN PART OF THE SAN JUAN BASIN, NEW MEXICO}

\author{
By Carle H. Dane, Erle G. Kauffman, ${ }^{1}$ and William A. Cobban
}

\section{ABSTRACT}

A sandstone member in the lower part of the Mancos Shale in northwestern Sandoral County, N. Mex., is herein named the Semilla (pronounced Say-meéyah) Sandstone Member from outcrops along the west side of the valley of Arroyo Semilla in the northern part of the San Ysidro 15-minute quadrangle. It has a north-south extent of about 35 miles and a known east-west extent of 7 or 8 miles. Its base lies about 200 feet above the top of the Greenhorn Limestone Member of the Mancos Shale. The thickest known beds ( $69 \mathrm{ft} ., 9 \mathrm{in}$.) were measured as the type section at an easily accessible exposure about 2,000 feet northeast of Holy Ghost Spring (Ojo del Espiritu Santo), which is about 1 mile east of New Mexico Highway 44 at a point about $7 \frac{1}{2}$ miles south of La Ventana store.

The member is composed of a very well sorted fine- to medium-grained sandstone with several persistent zones of calcareous concretions. Slightly more than half of the sand grains in the upper part of the member are quartz; 20 percent are microcline and orthoclase, many with perthitic texture; 20 percent are fragments of a variety of rocks; and $\mathbf{1 0}$ percent are plagioclase feldspar. The sandstone is remarkably free of ferromagnesian minerals.

The Semilla Sandstone Member contains a moderately abundant marine molluscan fauna, chiefly of bottom-dwelling forms, characteristic of the Prionocyclus hyatti zone of middle Turonian age. In the upper part, the fauna is closely comparable with that of the Codell Sandstone Member of the Carlile Shale of Kansas, southeastern Colorado, and northeastern New Mexico, and in the lower part, with that of the upper part of the Blue Hill Shale Member of the Carlile Shade of Colorado and Kansas.

The Semilla Sandstone Member was deposited in shallow marine waters from rather evenly flowing offshore currents. A nearby source area of plutonic rocks or of older sedimentary rocks derived chiefly from plutonic rocks is probable; this source area may have been an island undergoing active shoreline erosion.

\section{OCCURRENCE}

In the southeastern part of San Juan Basin, New Mexico, a distinctive, locally conspicuous, and moderately persistent sandstone unit in the lower part of the Mancos Shale lies about 200 feet above

\footnotetext{
IDepartment of Paleobiology, U.S. National Museum, Washington, D.C.
} 
the top of the Greenhorn Limestone Member of the Mancos Shale. A variable few feet of dark shale separates the top of the sandstone unit from the Juana Lopez Member of the Mancos Shale as defined by Dane, Cobban, and Kauffman (1966). This sandstone unit, which is as much as 70 feet thick, is here named the Semilla Sandstone Member of the Mancos Shale. The name is taken from the Arroyo Semilla, where the upper part of the sandstone crops out along the northwest side for some miles in a continuous low northeast-trending cuesta (figs. 1 and 2). The type area is near the Holy Ghost Spring Recreation Area on lands now belonging to the Jemez Pueblo, which are within the Ojo del Espiritu Santo Grant. The type section (fig. 3) is readily accessible and is about 2,000 feet north of Holy Ghost Spring (Ojo del Espiritu Santo) and approximately 1 mile east of New Mexico State Highway 44 at a point about $71 / 2$ miles south of La Ventana store (fig. 1); it is described in detail at the end of this report. The Semilla Sandstone Member is known to crop out west of San Ysidro from the northern parts of T. 14 N., R. 1 E., and T. 14 N., R. 1 W., and to extend northward across the San Ysidro 15-minute quadrangle and thence northward into the steeply dipping beds in the foothills belt west of the Nacimiento Mountains, and perhaps intermittently, into sec. 11, T. 20 N., R. 1 W., in the northern part of the La Ventana quadrangle. The known north-south outcrop belt is about 35 miles long and the maximum east-west extent of the member is 7-8 miles. The sandstone member grades northward into silty shales and loses its identity in the northeastern San Juan Basin.

\section{LITHOLOGY}

At the type area the Semilla is divisible into two lithic units: (1) a 45-foot-thick lower unit of very fine grained silty poorly bedded yellowish-brown sandstone containing six zones of large rounded brown calcareous sandstone concretions (figs. 3 and 4); and (2) an upper unit, 25 feet thick, consisting of somewhat darker colored and coarser grained, massive, ledge-forming sandstone and a few harder, brown-weathering sandstone beds. Fossils occur abundantly in the concretions and in small lenses of the upper sandstone unit, especially near the top.

The sandstone in the Semilla is characteristically well sorted, but the sorting is commonly masked throughout by carbonate, ferruginous, or siliceous cement, and, in the upper part of the member, by extensive secondary overgrowths of quartz on quartz grains. The overgrowths develop numerous well-defined crystal faces and, less commonly, doubly terminated quartz crystals. In general, the sandstone of the lower part of the member contains 70 percent very fine sand to fine sand 


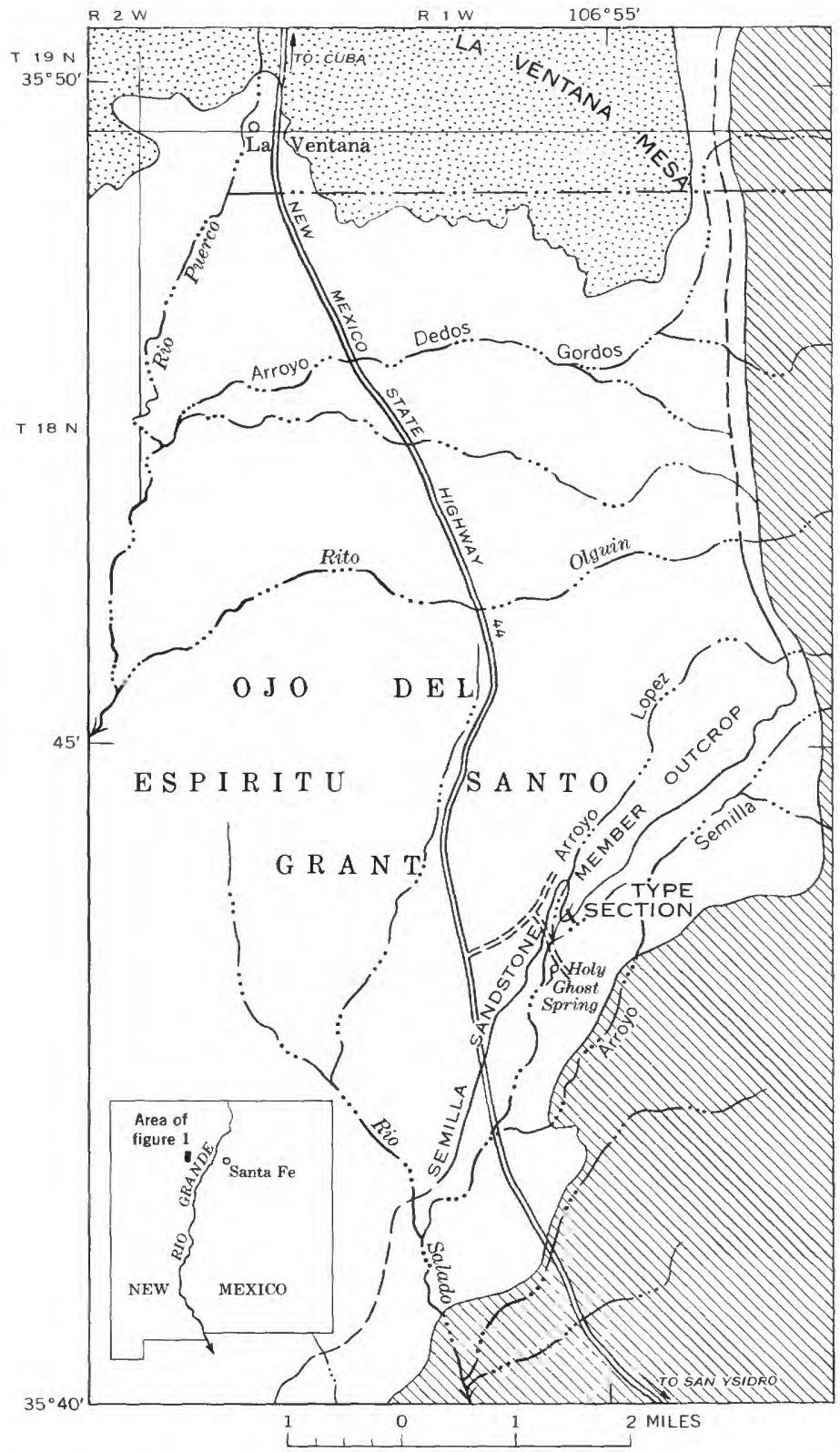

Figure 1.-Location of the type section of the Semilla Sandstone Member of the Mancos Shale and its outcrop in the nearby area. Mesaverde Group stippled, Dakota Sandstone and older rocks diagonally lined, Mancos Shale unpatterned. Base from parts of San Ysidro and La Ventana 15-minute topographic maps. 


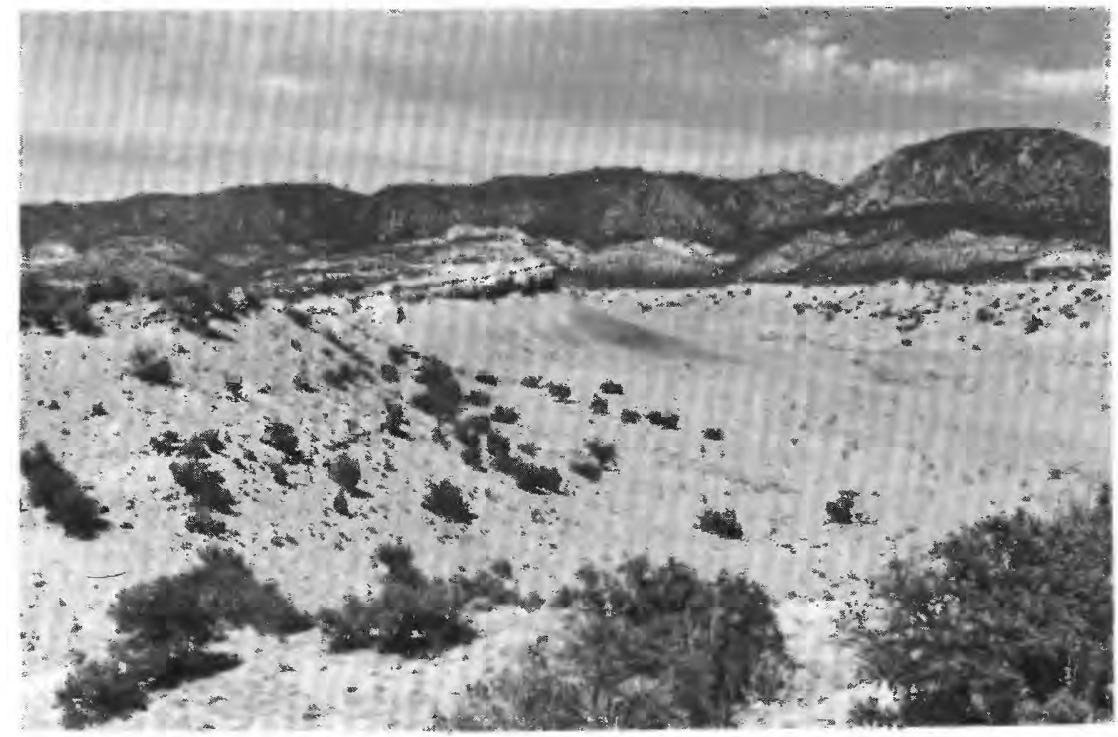

Frgune 2-Cuesta ridge made by the Semilla Sandstone Member of the Mancos Shale northeast of type section and by the underlying dark-gray shale of Carlile age exposed along a short valley tributary to Arroyo Lopez. Nacimiento Mountains on skyline.

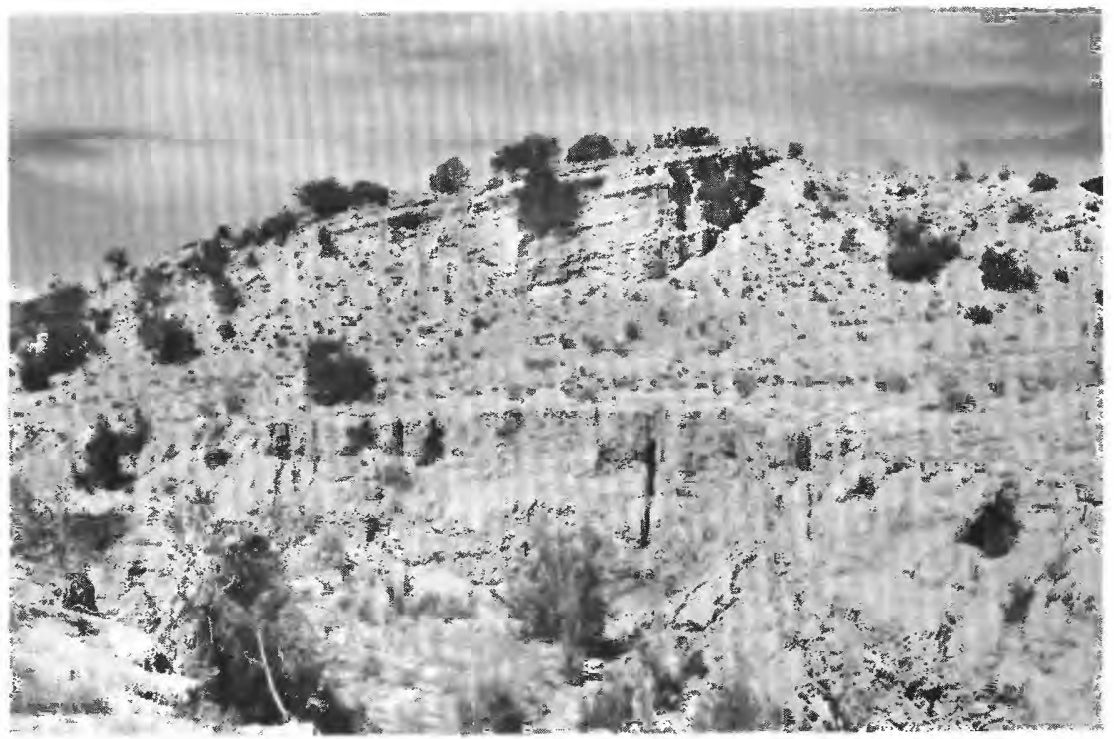

Frgure 3.-Type section of the Semilla Sandstone Member of the Mancos Shale showing the upper zones of concretions in a vertical face just east of Arroyo Lopez and 2,000 feet north of Holy Ghost Spring (fig. 1). 


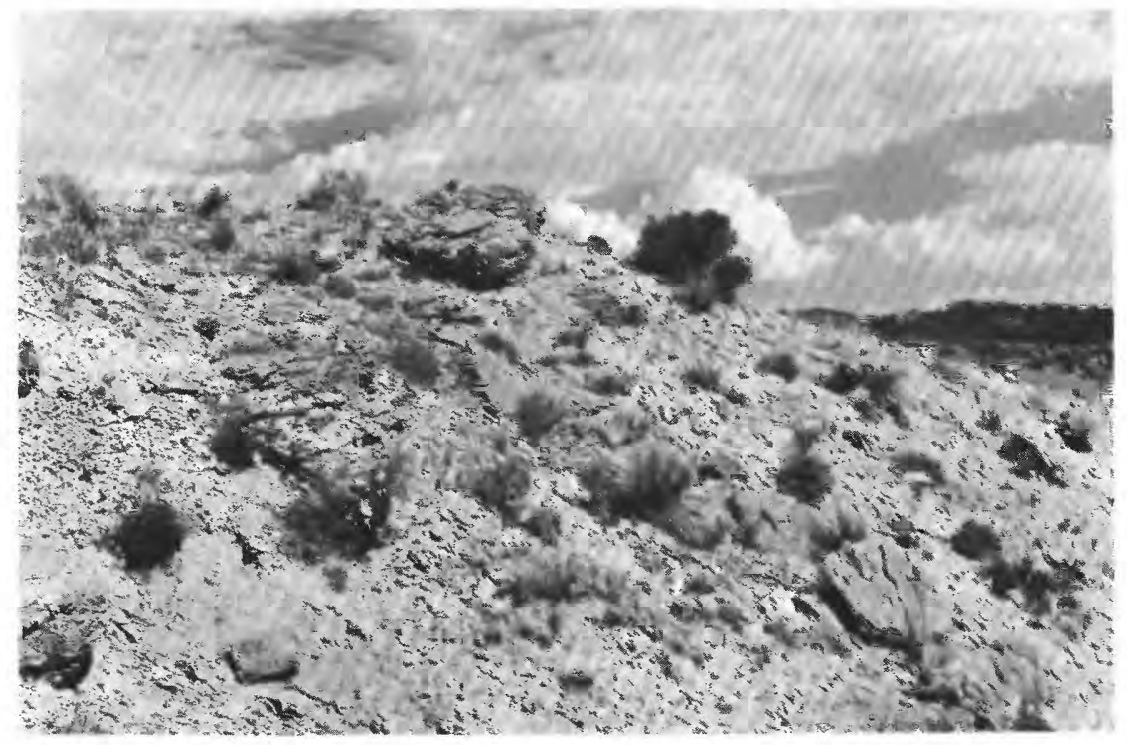

FIgure 4.-Concretions weathered out of the lower part of the Semilla Sandstone Member of the Mancos Shale at the type locality. Concretions are 2-3 feet in diameter.

(mostly very fine sand), 10 percent silt and clay sized particles, and 20 percent calcium carbonate. In the middle part of the member, the sandstone contains about 80 percent very fine to fine sand (mostly fine sand); the remainder is silt, clay, and calcium carbonate. In the upper part of the member, the sandstone contains about 80 percent fine sand and medium sand sized grains in nearly equal parts; the remainder consists of finer sized material and ferruginous and siliceous cement with only a small amount of carbonate. In general, there is thus a gradual increase in average grain size upward and a gradual change from the dominantly carbonate cement in the lower part to principally ferruginous and siliceous cement in the upper part.

The mineralogic composition of the coarser grained upper part of the Semilla was examined for the writers in May 1966 by Roy A. Bailey of the U.S. Geological Survey, who reviewed several thin sections of samples taken from two localities. The first of these samples was taken near the top of the Semilla about a mile and a half southwest of the type section, just east of New Mexico Highway 44. Mr. Bailey described this rock as

a medium-grained, feldspathic sandstone consisting predominantly of subangular to rounded grains $(0.2-0.7 \mathrm{~mm}$ diam) of quartz (more than 50 percent), microcline and orthoclase (about 20 percent), plagioclase (about 10 percent), 
and a wide variety of sand-size rock fragments (about 20 percent). Small fragments of bone (dahllite and collophane) are also moderately abundant.

The quartz grains invariably have wavy extinction and contain abundant minute inclusions commonly alined in healed fractures. Most of the inclusions are too small for identification, but rutile needles and occasional larger crystals of apatite, tourmaline, zircon, and epidote are recognizable. All of the quartz grains have conspicuous secondary overgrowths of quartz.

Both microcline and orthoclase grains show a wide variety of perthitic textures and some sericitic alteration. Plagioclase shows twinning but seldom any zoning and is commonly clouded by a fine-grained, brownish alteration product.

A microgranular variety of chert is the most abundant rock fragment. (Chalcedonic chert is rare.) A particularly distinctive type of chert is a microgranular variety containing abundant euhedral grains of magnetite pseudomorphed by hematite. Some of the rock fragments appear to be fine-grained altered volcanics, but only a few grains of pilotaxitic basalt or andesite could be positively identified as of volcanic origin.

The cementing material is largely authigenic quartz forming overgrowths on the quartz grains. Most of these overgrowths $(0.02-0.03 \mathrm{~mm}$ thick) are optically continuous with detrital cores. Overgrowths on adjacent grains are commonly grown together and are in irregular contact, but adjacent to interstices the overgrowths have well-developed crystal faces. A very minor amount of carbonate cement is present also.

The character of the inclusions in the quartz grains, the abundance of perthitic feldspars, and the lack of zoning in the plagioclases indicate that the bulk of the materials was derived ultimately from a crystalline (igneous and (or) metamorphic) terrane. However, the sandstone is remarkably free of ferromagnesian detrital grains, which, together with the abundance of chert fragments, suggests that it may be a second cycle sediment.

Mr. Bailey also examined thin sections cut from a sample taken from the upper 6 feet of the Semilla at the type section. He described this rock as

a medium-grained feldspathic sandstone consisting of subangular to subrounded grains $(0.1-0.5 \mathrm{~mm}$ diam) of quartz (about 50 percent), feldspar (about 20 percent), and rock fragments (about 30 percent) in a ferruginous cement.

This sandstone is similar to the one first examined but is slightly finer grained, and the grains tend to be somewhat less rounded. The quartz overgrowths so prominent in the first sample are lacking, but the quartz grains otherwise are similar, having wavy extinction and abundant inclusions. Microcline, orthoclase, and plagioclase are present in proportions similar to the first section examined, and they exhibit similar textural and alteration characteristics.

Sand-size fragments of chert, microgranular vein quartz, aplite, and variety of microcrystalline volanic(?) rocks are present, but the distinctive magnetite(hematite-) bearing chert of the first sample is absent and bone fragments are less abundant.

This rock is also clearly derived from a crystalline source area and like the first sample, it contains almost no ferromagnesian grains. 


\section{REGIONAL VARIATION}

The type section of the Semilla Sandstone Member is the thickest sequence ( $69 \mathrm{ft}, 9 \mathrm{in}$ ) that has been observed. The member varies rather erratically in thickness throughout its geographic extent.

About 4 miles northeast of the type locality the member is represented by about 17 feet of soft muddy white sandstone with a few hard brown calcareous concretions containing Inoceramus howelli White and Cardium sp. About 5 miles farther north, the Semilla is represented by a few feet of siltstone. At the equivalent horizon 8 miles still farther north, however, there is nearly 30 feet of siltstone and very fine grained light-colored sandstone containing Pinna sp., oysters, and indetermine small pelecypods; in the lower part are large hard brown sandy calcareous concretions. This locality, in the NE $1 / 4$ sec. 11, T. 20 N., R. 1. W., on the north side of Senorito Arroyo, La Ventana quadrangle, is the farthest north the Semilla Sandstone Member has been observed by the authors. Southward from the type locality, however, its outcrop extends almost continuously for more than 20 miles in the western part of the San Ysidro 15-minute quadrangle and tha adjoining area to the south.

South of the type locality, the Semilla exhibits the same irregularity in thickness and character as it does north of the type locality. Its outcrop extends for more than 2 miles southwestward from the type section in a well-defined low escarpment crossing New Mexico Highway 44, where there are good exposures in the highway cut and north of the highway. It diminishes considerably in thickness, however, until it is no longer topographically expressed about a mile southwest of the highway where only a few siltstone beds crop out. About a mile and a half southwest of the highway the member is represented only by a few brown concretions in a unit of gray and brown sandstone beds that are a fraction of an inch in thickness. For about 9 miles in the southwestern part of San Ysidro quadrangle and from 1-2 miles east of the western edge of the quadrangle, the Semilla is represented by 25-50 feet of soft silty sand or siltstone with large hard brown sandy calcareous concretions. At one locality (about 6 miles north of the southern edge of the quadrangle, 1.1 miles southwest of Ojito Spring) the lowest zone of large rusty-brown concretions contains very large numbers of Spathites puercoensis (Herrick and Johnson).

Near the southern edge of the San Ysidro quadrangle in the western part of sec. 17 and the northeastern part of sec. 18, T. 15 N., R. 1 W., 
bedded sandstone 3 or 4 feet thick again overlies the soft muddy siltstone or sandstone with brown concretions. As at the type locality, the contact with the overlying shales appears to be quite sharp.

Although the Semilla Sandstone Member has not been traced south of the San Ysidro quadrangle, similar sandstones have been noted at several localities to the south and east of the type area. At this time of writing, this sandstone is not known to be present on the south side of Mount Taylor north of U.S. Highway 66 except probably at one locality. In the SW1/4 sec. 4, T. 10 N., R. 7 W., on the west side of San José Canyon, a massive to weakly bedded sandstone 8-10 feet thick lies within a few feet below the basal part of the Juana Lopez Member of the Mancos Shale. The sandstone contains Callianassa borings but no other fossils; it is sharply defined at the top but at the base grades into dark-gray silty shale. The Semilla is also probably equivalent to an unnamed sandstone in the Galisteo-Tonque area (Stearns, 1953, p. 968) which is described as "thin hard sandstone forms a persistent hogback below the Juana Lopez Member in the Galisteo Lowland. The sandstone is generally only 1 or 2 feet thick, but at one locality in the southeast part of the Galisteo Lowland, soft massive sandstone below the principal bed increases the thickness to 30 feet."

The Semilla is not present north of Cerrillos at the type locality of the Juana Lopez Member although 28 feet of silty shale, bearing very thin lenticular sandstones, siltstones, and five septarian concretion zones occurs 90 feet below the Juana Lopez Member and probably represents a shale facies equivalent to the Semilla. Concretions in shale about 150 feet below the base of the Juana Lopez contain a fauna of the Prionocyclus hyatti zone. A few miles to the north, at a locality about 12 miles southwest of Santa Fe along U.S. Highway 85, approximately 40 feet of silty shale lies about 40 feet below the base of the Juana Lopez; this silty shale contains warty septarian concretions at several levels and a few thin siltstone beds with a fauna of the $P$. hyatti zone. Although these silty units should not be considered a part of the Semilla Sandstone member, they lie within or proximal to the hyatti fauna and indicate at least local deposition of finely clastic material at an equivalent level. Similarly, far to the northwest in the type area of the Mancos Shale in southwestern Colorado, about 10 feet of silty shale and thin siltstone beds containing the $P$. hyatti fauna lies about 50 feet below the base of the Juana Lopez Member. The basal sandstone of the Straight Cliffs Formation of southwestern Utah is also age equivalent, but neither the $P$. hyatti zone nor a sandstone unit equivalent to the Semilla is recog- 
nized in the intervening Black Mesa, Arizona area (Repenning and Page, 1956, p. 268).

\section{FAUNAL CONTENT AND CORRELATION}

The Semilla Sandstone Member at the type section lies entirely within the ammonite zone of Prionocyclus hyatti (Stanton) as defined by Cobban and Reeside (1952, chart 10b, p. 1018). In south-central Colorado and Huerfano Park, this zone is divisible into two subzones on the basis of unnamed species of Turritella, subspecies of Lopha bellaplicata (Shumard), and species of Inoceramus (Kauffman, 1961, 1965).

The lower subzone occurs in the upper part of the Blue Hill Shale Member of the Carlile Shale, which contains septarian limestone concretions; it is characterized in south-central Colorado and in parts of Kansas (Hattin, 1962) by Lopha bellaplicata novamexicana Kauffman, Inoceramus cuvieri Sowerby and forms transitional between this species and $I$. howelli White, and a new turritellid which we here designate Turritella $\mathrm{n}$. sp. A. This subzone also contains a diverse molluscan fauna similar to that of the overlying Codell Sandstone Member ("Pugnellus Sandstone" of Stanton, 1893).

The upper subzone in south-central Colorado contains the diverse "Pugnellus Sandstone" fauna described by Stanton in 1893 and is characterized by the presence of Lopha bellaplicata bellaplicata (Shumard), Inoceramus howelli f.t., a new turritellid here designated Turritella $\mathrm{n}$. sp. B, and the absence of $I$. cuvieri. Coilopoceras colleti Hyatt is also found in this subzone.

The upper resistant sandstone unit of the Semilla Sandstone Member includes the upper part (upper subzone) of the $P$. hyatti zone and is thus the age equivalent of the Codell Sandstone Member of southcentral Colorado. This is confirmed by the presence in the resistant sandstone unit of the Semilla of Lopha bellaplicata bellaplicata, Inoceramus howelli without $I$. cuvieri, Turritella n. sp. B, and possibly also by the presence of a new species of oyster known previously only from the younger Juana Lopez Member.

The soft concretion-bearing sandstone unit that forms the lower part of the Semilla Sandstone Member seems to be equivalent to the upper part of the Blue Hill Shale Member of Colorado and Kansas (commonly silty and sandy, with several zones of septarian limestone concretions), and it represents the upper part of the lower $P$. hyatti subzone. The presence of Inoceramus howelli subsp. transitional to 1. cuvieri and possibly the occurrence of Spathites puercoensis and of Coilopoceras springeri instead of $C$. colleti suggest this correlation. 
Despite their lithologic and, in part, age equivalence, the Codell Sandstone Member of Colorado and the Semilla Sandstone Member of New Mexico do not form a continuous sand body; instead, they are separated by nearly 100 miles of shale without sand that is of equivalent age; therefore, the introduction of a new name for the New Mexico unit seems justified.

\section{CONDITIONS OF DEPOSITION}

\section{LITHOLOGIC EVIDENCE}

Many sections of the Semilla Sandstone Member that have been examined, including the type section, display the general habit of the shallow marine sublittoral sandstones of the western interior Cretaceous as described by Spieker $(1949$, p. 62,64$)$; that is, a gradation upward from shales into increasingly coarser siltstones and sandstones, with a clear-cut upper boundary that normally has a hard brown ferruginous carbonate-cemented sandstone bed at the top at places where the sandstone unit is overlain by marine shale. The transitional base of such marine sandstones represents the transition from mud to sand in the zone of shallow shelf deposition beyond the marginal sand sheet, and owes its origin to either a gradual influx of clastic material or a retreat of the sea. Although the clean-cut upper boundary of some such marine sandstones represents a subaerial gradation plane (Spieker, 1949, p. 64), for others, such as the Semilla, the sharp top results from a buildup of clastic material into shallower and shallower waters in which agitation by waves and transport by offshore currents created a bypass sedimentation condition and prevented the further accumulation of sand. Thus, submarine erosion resulted in a planar upper surface bevelling crossbedding planes in the sand deposit, as in the type section of the Semilla, where the upper two units (22 and 23, p. 25) thicken markedly in a northwesterly direction. As in other regressive marine sandstones, granules and pebbles characteristically occur locally in the upper part of the Semilla. This coarse material has been variously attributed to rapid accumulation and poor sorting; to winnowing; and, in beach deposits, to the rapid lodgement of gravel on beach surfaces by quick wave pulses with sudden acceleration of velocity transporting coarser material than was returnable by slower back flowing of ebbing wave water (Barrell, 1925, p. 295). The coarse material observed in the Semilla has been found in poorly sorted crossbedded units associated with fragmented oyster shells, and their presence suggests episodes of winnowing during rapid accumulation.

Throughout the Semilla, the grains are well sorted within a narrow range of particle sizes, and this indicates that they were deposited by 
marine currents flowing at a rather steady rate. A relatively sudden change in depositional environment probably caused the rather abrupt gradation from shale at the base of the member to dominantly very fine grained sandstone above. The gradual coarsening of grain size upward in the member indicates the increasing velocity of the currents that introduced and distributed the sediments, and this condition, presumably though not necessarily, reflects a closer approach of the shoreline to the outcrop area. The upward decrease in the proportion of clay matrix to sand can be related to increasingly shallow depth, increasing wave turbulence, and winnowing of the sediment, as Sabins (1963, p. 220) has noted for the bar sands of the Bisti area in the northwestern part of the San Juan Basin.

The angularity of the quartz grains in some of the coarser parts of the Semilla has been greatly overemphasized because secondary overgrowths have produced remarkably sharp crystal faces on originally rounded grains, nevertheless, there are many subangular to angular original grains of quartz, feldspar prisms, and other rock fragments in the sandstone. The general angularity of these various grains in the Semilla suggest the possibility that the source area was not far away; however, there is another possible explanation for the preservation of the angularity of the fine grains, that the currents which transported them over a long distance were either of uniform moderate velocity or of sufficiently high velocity to cause the grains to saltate or remain suspended.

The rarity of ferromagnesian minerals may be due, as suggested by Bailey, (p. F6), to the fact that the Semilla represents a second cycle sediment. Alternative possibilities are that the relatively evenly flowing currents, from which the sand was deposited, moved for such considerable distances that the heavier minerals dropped out by gravity separation before reaching the rather limited site of deposition to which the outcrop of the Semilla is now restricted, or that the source area contained an unusually low amount of ferromagnesian minerals. Locally in the lower part of the member, small muscovite flakes and a very few flakes of oxidized biotite are present with coarser quartz, feldspar, and rock grains. These mica flakes, because of their shape, would be the most buoyant and transportable of the ferromagnesian minerals.

\section{PALEONTOLOGIC EVIDENCE}

Insofar as the ecologic significance of the faunas of the Semilla is interpretable, it accords with and supports the physical evidence of conditions of deposition. The abundance of mollusks and arthropods that have living representatives inhabiting nearshore sandy substrate is evidence of an active shallow-water marine environment. Among 
the fauna are plicate oysters, Pinna, Cymbophora (a mactrid), Turritella, Trigonarca, Tellina, Cardium, and others. The beds are riddled to within 15 feet of the top of the member at several levels by the burrowings of marine worms and callianassid crabs. The presence of a crab carapace in the collections is accordant. The distribution of species of ammonites in the Semilla is also apparently accordant. The paleoecological significance of the ammonites has been briefly summarized by Birkelund (1965), and although apparently no consensus has been reached, it seems likely that Hattin's suggestion (1962, p. 121) that Prionocyclus hyatti and Scaphites are bottom dwelling ammonites is correct and that the smooth discoidal ammonites such as Placenticeras and Coilopoceras are nektonic or planktonic forms. Prionocyclus hyatti is found nearly throughout the Semilla but thus far Coilopoceras springeri has been found only in the lower part. If further collections confirm this difference in occurrence of the ammonites, then the difference in assemblages could be interpreted to represent an upward change of sediments deposited from moderate depths to shallower depths with possible inshore conditions where shells of nektonic ammonites would be less likely to be found. The unique abundance of adult specimens of the otherwise rare species Spathites puercoensis (Herrick and Johnson), a smooth-shelled presumably nektonic tissotid ammonite, at a locality 1.1 miles S. $10^{\circ} \mathrm{W}$. of Ojito Spring in the basal part of the Semilla is of special interest. Birkelund (1965, p. 145) has suggested that such concentrations represent the remains of breeding swarms of a nektonic species migrating en masse and especially sensitive to changes in salinity, temperature, and (or) other controls. It is clear that an abrupt change in physical conditions would likely be encountered marginal to or with the relatively abrupt onset of a sediment-laden marine current such as the one postulated as the transporting vehicle for the Semilla Sandstone Member.

\section{SOURCE}

Although conclusions about the environment of deposition seem rather firmly established, inferences as to source are speculative and will remain so until more detailed petrographic and sedimentary structural studies have been made of the Semilla and other sandstones in the Cretaceous sequence.

The general northwesterly inclination of the crossbedding and the general southeast onlap of beds in the upper part of the Semilla near the type section clearly indicate deposition from northwesterly directed currents. It is highly probable that these currents were directed seaward from a source of supply that lay to the southeast inasmuch as the unit terminates on the outcrop both northeast and southwest of the type locality. This interpretation is substantiated by the geographic loca- 
tion of the deposit as well as by the fact that it is thickest and contains most clastic material in the central part of its area of outcrop.

Rocks that are time equivalent to the Semilla are found to the southwest in the Cebolleta Mesa area and the Datil Mountain coal field area; they thicken and become coarser grained to the southwest and were obviously derived from the southwestern source common to most of the Upper Cretaceous clastics of northwestern New Mexico. A considerable geographic gap separates these time equivalent rocks from the Semilla, which has a different pattern of distribution. The writers know of no evidence of equivalent clastic rocks on the outcrop or in the subsurface of the San Juan Basin to the northwest, and there are none for a very long distance to the northwest. Therefore, there must have been a local source not far to the southeast for the Semilla sediments, although there is no other evidence of uplift in that area at that time. Muehlberger, Adams, Longgood, and St. John (1960, p. 95) have evidence to support the theory of a local source to the northeast in the Brazos uplift for the Dakota Sandstone in the Chama area. Such a source would indicate that even at the beginning of the Late Cretaceous local sources were adding to the supply of clastic detritus from southwestern New Mexico.

As Bailey has pointed out (p. F6), the petrographic character of the Semilla shows that much of it was derived, at least ultimately, from plutonic rocks. To the writers, the abundance of feldspars of several plutonic types and their lack of deep alteration suggests that most of them were derived directly from rocks of an igneous or metamorphic terrane rather than from older sandstone beds. The chert grains of various kinds, on the other hand, bespeak a source from older Paleozoic rocks, which quite likely also provided some of the rounded quartz grains. Some of the Semilla contains an estimated 20-30 percent grains of feldspar, they are subangular to angular, and include some cleavage fragments of feldspar. This seems to require a special explanation in view of the humid climatic conditions that prevailed during Late Cretaceous time in the central and western interior of the United States, where paleogeographic conditions permitted accumulation of materials such as carbonaceous detritus, leaf and stem impressions, and coal beds. As Hattin (1962, p. 117) has pointed out in an analysis of the possible source area for the Codell, the source area could not have been one of low relief because under the humid climatic conditions the feldspar would have been thoroughly decomposed.

On the contrary, if the source area had been one of high relief, there would be evidence of steep stream gradients such as, at least close to the source, an abundant supply of variably coarse clastic detritus. It seems unlikely that such a relatively fine-grained uniformly sized deposit as the Semilla could have been derived from such a source. (Hattin also 
showed that the kaolin found in the Blue Hill could not have originated under conditions of high relief.) As Pettijohn (1957, p. 125) has pointed out, feldspar can survive long transport in large streams, but if the source area for the Semilla was, as we have tentatively postulated, not many miles to the southeast of its present outcrop area, then a likely source area might have been a small island mass within the Cretaceous sea; however, there is no indication that such an island mass existed at the time of deposition of the Upper Cretaceous rocks that were deposited before the Semilla. If there had been such an island source area, the angularity and relative abundance of comparatively fresh feldspar in the Semilla could be explained as derived from shoreline erosion and submarine planation rather than from subaerial erosion followed by fluviatile transport. The foregoing speculations serve primarily to indicate the need for more intensive and also more extensive mineralogic, petrographic, and petrologic studies of these rocks to be coordinated with stratigraphic and paleontologic studies.

\section{PROBLEMS OF NOMENCLATURE}

The writers of this paper are in complete accord on the definition, lithologic characterization, faunal content, and correlation of the Semilla Sandstone Member. They do differ in their present opinions as to the way in which these should be expressed within the necessarily arbitrary framework of stratigraphic classification, and it seems desirable to consider these differences of opinion briefly at this time because further analyses of the stratigraphic relations of the rocks of Colorado age in the San Juan Basin by us and by other authors are already in preparation.

The details of the physical and age relationships between the section in the San Juan Basin and the sections in Kansas and eastern Colorado have not been clearly defined in papers published thus far. In Kansas and eastern Colorado the stratigraphic concepts of the Colorado Group were first formed and have since been extensively studied. The sequence in those areas is consistently divisible into extensive thin units, for they were sites of marine deposition that was relatively far offshore. Three formations are recognized in the lower (pre-Niobrara) part of the Colorado Group; in ascending order, they are the Graneros Shale, Greenhorn Limestone, and Carlile Shale. Detailed discussions of these units, as currently used, may be found in Rubey and Bass (1925, p. 32-53), Bass (1926, p. 26-35), Hattin (1962, 1965 a, b), Eicher (1965, p. 875-879), Dane, Pierce, and Reeside (1937), Scott $(1962,1963,1964)$, Kauffman (1965 p. 4-6), and Kauffman and Pope (1961, p. 1004-1009, text-fig. 2).

In general, the Graneros consists of dark noncalcareous clay shale containing numerous bentonites; the Greenhorn Limestone consists of 
gray chalky and calcareous clay shales with gray calcarenite bands in the lower part (Lincoln Limestone Member), gray to brown chalky shales with a few chalky limestones and calcarenites in the middle (Hartland Shale Member), and massive sublithographic limestone beds with intercalated chalky shale units at the top (Bridge Creek Limestone Member of Colorado). (The Bridge Creek Member is the original "Greenhorn Limestone" of Gilbert, 1897.)

The Carlile Shale consists of (in ascending order) a basal marly to chalky shale containing thin calcarenite bands and concretions (Fairport Chalky Shale Member); a middle dark-gray clay shale that is silty at the top and that contains numerous septarian limestone concretions in the upper half (Blue Hill Shale Member); a variable massive to slabby sandstone and sandy shale unit (Codell Sandstone Member); a thin rusty-brown calcarenite (Inoceramite)-bearing unit (Juana Lopez Member); and locally, a thin calcareous shale and a dark-clay shale member at the top (unnamed member). These units have been defined as far south as the Huerfano Park-Walsenburg areas of south-central Colorado (Johnson, 1959; Kauffman, 1961, 1965; Kauffman and Pope, $1961^{2}$ ) and are clearly recognizable (except locally for the Codell Sandstone Member) in northern and northeastern New Mexico (Rankin, 1944; Kauffman, unpub. data).

Rankin (1944), who first introduced the nomenclature of the Colorado Group from Colorado and Kansas into this area, clearly recognized the Graneros, Greenhorn, and Carlile as formations in northeastern New Mexico; however, his definitions of the Graneros and Greenhorn were those of Gilbert (1897) instead of those of Rubey and Bass (1925) and Bass (1926), whose definitions are in current use. In the northeastern part of the San Juan Basin, because the Graneros, Greenhorn, and Carlile seemed sufficiently distinct as lithologic units compared to their counterparts in Colorado, Dane and Bryson (1938) were led to recognize them as members of the Mancos Shale and subsequent workers have followed this lead (Muehlberger and others, 1960, p. 96 ; Smith and others, 1961, p. 17).

It is now known that the upper boundary of the rocks of Carlile age in the northeastern part of the basin falls at an as yet undetermined level in a shale unit above the Juana Lopez Member, although very probably only a few feet above the top of the Juana Lopez (Landis and Dane, 1968). Farther south in the southeastern part of the basin, however, a considerably greater thickness of beds of late Carlile age succeeds the Juana Lopez Member, and only about 10 miles southwest of the type locality of the Semilla Sandstone Member the boundary between rocks of Carlile and Niobrara age lies at the base of the

2 Juana Lopez Member and the overlying unnamed shale were included in the Codell in this paper. 
northeasterly tapering wedge edge of the Gallup Sandstone. There the rocks exposed are within that part of the San Juan Basin where complex marginal marine sand bodies, ranging from earliest Late Cretaceous to Montana in age, intertongue with the marine sequence. Some of these sand bodies are lenticular; some are demonstrably time transgressive. The lower ones have thus far been assigned to the Dakota Sandstone or to the sandstone members in the lower part of the Mancos Shale (Hunt, 1936, p. 40-42; Owen, 1966, and many others). The upper ones have been designated formations, some with component members, of the Mesaverde Group (Beaumont and others, 1956). In this southeastern part of the San Juan Basin, Carlile and Niobrara are not useful or practicable as rock stratigraphic names, although they will continue to have value in a time stratigraphic sense.

Dane and Cobban would prefer to retain, for the entire San Juan Basin of New Mexico and Colorado, the presently accepted classification of Dakota Sandstone, Mancos Shale, and Mesaverde Group with named formations and members of each as appropriate; and to indicate the equivalence in age, paleontology, and lithology with the KansasColorado sequence insofar as this can be done. Kauffman, on the other hand, would prefer to extend each of the Kansas-Colorado formation and member subdivisions as far as possible into the San Juan Basin. He would prefer to recognize Graneros, Greenhorn, and Carlile as formations within a Mancos Group as far as possible, with the top of the Carlile at the top of the Juana Lopez Member and above it an as yet unnamed and unmapped formation of late Carlile and early Niobrara age. Dane and Cobban believe that this approach, although theoretically preferable, imposes difficulties of stratigraphic treatment in regional papers that can be conveniently avoided by maintaining the formational status of the Mancos Shale throughout the San Juan Basin.

The Semilla Sandstone Member is herein established, for the present, as a member of the Mancos Shale rather than of the Carlile Shale. 


\section{TYPE SECTION}

\section{Type Section of Semilla Sandstone Member of Mancos Shale}

[From 2,000-3,000 feet north of Ojo del Espiritu Santo (Holy Ghost Spring) and about 1 mile east of New Mexico State Highway 44 on Ojo del Espiritu Santo Grant, San Ysidro quadrangle, Sandoval County, N. Mex. Measured by Carle H. Dane and Edward John, November 1962, and by Carle H. Dane and E. R. Landis, May 1963. Fossil collections by the foregoing and by W. A. Cobban, August 1963, and by Erle G. Kauffman and Gerald R. Paulson, June 1964]

Shale of late Carlile age:

Ft in.

24. Shale, dark to black, paper-bedded, with small gray septarian carbonate concretions.

Semilla Sandstone Member of Mancos Shale:

23. Sandstone, soft; weathering pale to dark yellowish orange; in rounded weathering beds $6-19$ in. thick. Unit thickens northwestward

22. Sandstone, medium-grained, hard; weathers yellowish brown (10YR5/2); thickens northwestward to as much

USGS 28875:

Prionocyclus hyatti (Stanton)

Inoceramus howelli White

Lopha bellaplicata bellaplicata (Shumard)

Ostrea malachitensis Stanton

Trigonarca sp. aff. T. obliqua Meek

Pinna sp. indet.

Tellina? sp. indet.

Syncyclonema? sp. indet.

Turritella n. sp. B

Anatina sp. indet.

21. Sandstone, soft, bedded, poorly exposed

20. Sandstone; somewhat harder than beds above and below; irregular in thickness

19. Sandstone, soft, indistinctly bedded, very fine grained; riddled with borings.

18. Siltstone, parting

17. Sandstone, light-gray; coarser grained than beds above and below, with some black siliceous pebbles up to $1 / 2$ in. in diameter; abundant oyster shell fragments; ranges to as much as $1 \mathrm{ft} 6$ in. in thickness.

USGS 28874 from this bed and overlying three units:

Ostrea malachitensis Stanton

Inoceramus n. sp. aff. I. dimidius White (Common in Codell Sandstone Member of Colorado)

Lopha bellaplicata bellaplicata (Shumard)

"Ostrea" sp. aff. "O." congesta Conrad

Ostrea n. sp. (Known from lower Juana Lopez Member of Huerfano Park, Colorado

Trigonarca aff. T. obliqua Meek

Collections from about this level about $150 \mathrm{yd}$ westsouthwest from type section contain Prionocyclus hyatti (Stanton), Pinna petrina White, and Ostrea malachitensis Stanton 
Type section of Semilla Sandstone Member of Mancos Shale-Continued

Semilla Sandstone Member of Mancos Shale-Continued

Ft in.

16. Sandstone, soft, lighter gray than units below, massive to poorly bedded, rounded weathering.......................

15. Sandstone; somewhat harder than adjacent beds.......

14. Sandstone, very soft, fine-grained, yellowish-gray $\ldots$

13. Siltstone, with thin streaks of gray shale............ 64

12. Sandstone, silty, soft, very fine grained, yellowish-gray ( $5 Y 7 / 2$ ), poorly bedded; contains roundish pale-yellowishbrown-weathering limy sandstone concretions from 5 in.$1 \mathrm{ft}$ in diameter. This and underlying concretion zones have a marked tendency to be alined in nearly continuous beds. Fossil collections (USGS 28873) made from this and the underlying five concretion zones are listed from the lowest concretion zone. Most specimens were collected from talus slope, in part below the Semilla Sandstone Member, and are questionably in place. Those species which occur in the upper three concretion zones in place are followed with a " $U$ "; those from the lower three zones are followed with an "L." The fauna seems to be consistently the same from all the concretion zones.....

11. Sandstone, silty, sof $t$, very fine grained; like second bed

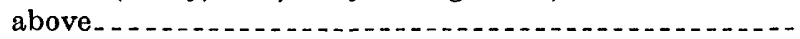

10. Sandstone; like beds above; contains rounded to ellipsoidal pale-yellowish-brown (10 YR6/2) weathering limy concretions as much as $2 \mathrm{ft}$ thick.

9. Sandstone, silty, soft, very fine grained.

8. Sandstone; like beds above; contains sandy limestone con-

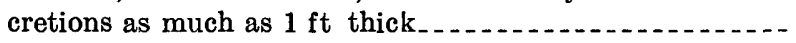

7. Sandstone, silty, soft, very fine grained......

6. Sandstone; like beds above; contains sandy limestone concretions as much as $1 \mathrm{ft} 6$ in. thick

5. Sandstone, silty, soft, very fine grained, up to $8 \mathrm{ft} 6$ in. thick.

4. Sandstone; like beds above; contains concretions up to $2 \mathrm{ft}$ thick and as much as $3 \mathrm{ft}$ along bedding with a few elongated across bedding.

3. Sandstone, silty, soft, very fine grained, yellowish-gray (5 $Y 7 / 2$ ), poorly bedded; some tendency to be subparallel to bedding; contains numerous "burrowings" of Callianassa? with elliptical cross sections as much as $11 / 2$ by 2 in., flared ends, and treelike branches at 6-inch intervals; some tendency to be subparallel to bedding........ 
Type section of Semilla Sandstone Member of Mancos Shale-Continued

Semilla Sandstone Member of Mancos Shale-Continued Ft in.

2. Sandstone; like beds above; contains sandy limestone concretions as much as $2 \mathrm{ft}$ thick USGS 28873:

Prionocyclus hyatti (Stanton) U L

Coilopoceras springeri Hyatt; common in upper part, rare in lower part.

Inoceramus howelli White U L

Inoceramus howelli $\mathrm{n}$. subsp., transitional to $I$. cuvieri Sowerby U L

Inoceramus $\mathrm{n}$. sp. aff. I. dimidius White U L (common in Codell Sandstone Member of Colorado).

Ostrea malachitensis Stanton U L

Syncyclonema? sp. indet.

Cardium sp. aff. C. pauperculum Meek L

"Cyrena" securis Meek

"Cyrena" n. sp.

Cymbophora? emmonsi Meek

Trigonarca sp. aff. T. obliqua Meek U

Sinonia n. sp. aff. S. levis Stephenson U

Anatina n. sp. aff. A. lineata Stanton U

"Ostrea" sannionis White, n. subsp.

Tellina n. sp. U

Tellina sp. immature

Xenophora simpsoni Stanton U L

Pyropsis? sp. indet. U

Crab carapace ef. Callianassa

"Burrowings" of Callianassa?

1. Sandstone, very fine grained, soft; grades downward into silty shale............ 60

Total thickness of Semilla Sandstone Member._. $\ldots \ldots \ldots 969$ Shale of Blue Hill (Carlile) age.

\section{REFERENCES}

Barrell, Joseph, 1925, Marine and terrestrial conglomerates : Geol. Soc. America Bull., v. 36, no. 2, p. 279-341.

Bass, N. W., 1926, Geologic investigations in western Kansas, with special reference to oil and gas possibilities; Pt. 1, Geology of Ellis County: Kansas Geol. Survey Bull. 11, p. 11-52.

Birkelund, Tove, 1965, Ammonites from the Upper Cretaceous of west Greenland: Medd. om Gronland, v. 179, no. 7, p. 141-151.

Beaumont, E. C., Dane, C. H., and Sears, J. D., 1956, Revised nomenclature of Mesaverde group in San Juan Basin, New Mexico: Am. Assoc. Petroleum Geologists Bull., v. 40, no. 9, p. 2149-2162.

Cobban, W. A., and Reeside, J. B., Jr., 1952, Correlation of the Cretaceous formations of the Western Interior of the United States: Geol. Soc. America Bull., v. 63 , no. 10, p. 1011-1044. 
Dane, C. H., and Bryson, R. P., 1938, Preliminary map showing geologic structure of part of Rio Arriba County, New Mexico: U.S. Geol. Survey General Mineral Resources (Prelim.) Map, 1: 63,360.

Dane, C. H., Cobban, W. A., and Kauffman, E. G., 1966, Stratigraphy and regional relationships of a reference section for the Juana Lopez Member, Mancos Shale, in the San Juan Basin, New Mexico: U.S. Geol. Survey Bull. 1224-H, 15 p.

Dane, C. H., Pierce, W. G., and Reeside, J. B., Jr., 1937, The stratigraphy of the Upper Cretaceous rocks north of the Arkansas River in eastern Colorado: U.S. Geol. Survey Prof. Paper 186-K, p. 207-232.

Eicher, D. L., 1965, Foraminifera and biostratigraphy of the Graneros Shale: Jour. Paleontology, v. 39, no. 5, p. 875-909, 4 figs., 4 pls.

Gilbert, G. K., 1897, Description of the Pueblo quadrangle, Colorado: U.S. Geol. Survey Geol. Atlas, Folio 36.

Hattin, D. E., 1962, Stratigraphy of the Carlile Shale (Upper Cretaceous) in Kansas : Kansas State Geul. Survey Bull. 156, 155 p.

- 1965a, Upper Cretaceous stratigraphy, paleontology, and paleoecology of western Kansas, in Geol. Soc. America Field Conf. Guidebook, Kansas City, Missouri, 1965 : p. 1-69.

-1965b, Stratigraphy of the Graneros Shale (Upper Cretaceous) in central Kansas: Kansas Geol. Survey Bull. 178, 83 p.

Hunt, C. B., 1936, Geology and fuel resources of the southern part of the San Juan Basin, New Mexico, pt. 2, The Mount Taylor coal field: U.S. Geol. Survey Bull. 860-B, p. 31-80.

Johnson, R. B., 1959, Geology of the Huerfano Park area, Huerfano and Custer Counties, Colorado: U.S. Geol. Survey Bull. 1071-D, p. 87-119, pls. 4-9, fig. 11 [1960].

Kauffman, E. G., 1961, Mesozoic paleontology and stratigraphy, Huerfano Park, Colorado: Unpub. Ph. D. Thesis, Univ. Michigan, 1401 p.

1965, Middle and Late Turonian oysters of the Lopha lugubris group: Smithsonian Misc. Colln., v. 148, no. 6, pub. 4602, p. 1-92, 8 pls.

Kauffman, E. G., and Pope, J. K., 1961, New species of Ringicula from the Upper Cretaceous of Huerfano County, Colorado, and remarks on the "Pugnellus Sandstone" (Codell Sandstone Member, Carlile Shale) : Jour. Paleontology, v. 35, no. 5, p. 1003-1013.

Landis, E. R., and Dane, C. H., 1968, Geologic map of the Tierra Amarilla quadrangle, New Mexico: New Mexico Bur. Mines and Mineral Resources Map [in press].

Muehlberger, W. R., Adams, G. E., Longgood, T. E., and St. John, B. E., 1960, Stratigraphy of the Chama quadrangle, northern Rio Arriba County, New Mexico, in New Mexico Geol. Soc. Guidebook 11th Field Conf., October 1960, Rio Chama Country : p. 93-102.

Owen, D. E., 1966, Nomenclature of Dakota Sandstone (Cretaceous) in San Juan Basin, New Mexico and Colorado: Am. Assoc. Petroleum Geologists Bull., v. 50, no. 5, p. 1023-1028.

Pettijohn, F. J., 1957, Sedimentary rocks [2d ed.] : New York, Harper \& Bros., $718 \mathrm{p}$.

Rankin, C. H., 1944, Stratigraphy of the Colorado group, Upper Cretaceous, in northern New Mexico: New Mexico School of Mines, Bur. Mines Mineral Resources Bull. 20, p. 1-30. 
Repenning, C. A., and Page, H. G., 1956, Late Cretaceous stratigraphy of Black Mesa, Navajo and Hopi Indian Reservations, Arizona: Am. Assoc. Petroleum Geologists Bull., v. 40, no. 2, p. 255-294.

Rubey, W. W., and Bass, N. W., 1925, The geology of Russell County, Kansas, with special refenence to oil and gas resources: Kansas Geol. Survey Bull. 10, p. 1-86.

Sabins, F. F., Jr., 1963, Anatomy of stratigraphic trap, Bisti Field, New Mexico: Am. Assoc. Petroleum Geologists Bull., v. 47, no. 2, p. 193-228.

Scott, G. R., 1962, Geology of the Littleton quadrangle, Jefferson, Douglas, and Arapahoe Counties, Colorado : U.S. Geol. Survey Bull. 1121-L, 53 p. 1963, Bedrock geology of the Kassler quadrangle, Colorado: U.S. Geol. Survey Prof. Paper 421-B, p. 71-125.

1964, Geology of the Northwest and Northeast Pueblo quadrangles, Colorado: U.S. Geol. Survey Misc. Geol. Inv. Map I-408.

Smith, C. T., Budding, A. J., and Pitrat, C. W., 1961, Geology of the southeastern part of the Chama Basin: New Mexico Bur. Mines and Mineral Resources Bull. 75, 57 p., illus.

Spieker, E. M., 1949, Sedimentary facies and associated diastrophism in the Upper Cretaceous of central and eastern Utah in Longwell, C. R., chm., Sedimentary facies in geologic history: Geol. Soc. America Mem. 39, p. 55-82.

Stanton, T. W., 1893, The Colorado formation and its invertebrate fauna: U.S. Geol. Survey Bull. 106, 288 p. 45 pls. [1894].

Stearns, C. E., 1953, Upper Cretaceous rocks of the Galisteo-Tonque area, northcentral New Mexico: Am. Assoc. Petroleum Geologists Bull.. v. 37. no. 5. p. 961-974. 




\section{CONTRIBUTIONS TO STRATIGRAPHY}

"Contributions to stratigraphy" in the Geological Survey's Bulletin series, consists of reports dealing primarily with stratigraphy, including those defining changes in stratigraphic nomenclature in reports of the Geological Survey. About 40 short reports pertaining to one or several stratigraphic units have been published or are in press. Like other Survey publications, these are announced in the monthly "New publications of the U.S. Geological Survey." In addition to reports on specific problems, an annual report within the series lists all changes in stratigraphic nomenclature such as (1) new names, (2) previously used names now adopted, (3) revised names, (4) changes in age designations, and (5) abandoned names. The age of the unit, the area in which the name is employed, the title of the pertinent report, and the publication in which the change is described are given. Thus far, the following reports dealing with annual compilations of changes in stratigraphic nomenclature have been published:

Bulletin 1194-A (for 1963). 20c
Bulletin 1224-A (for 1964). 30c
Bulletin 1244-A (for 1965). 25c
Bulletin 1254-A (for 1966). 20c

U. S. GOVERNMENT PRINTING OFFICE : 1968 O - 289-085 